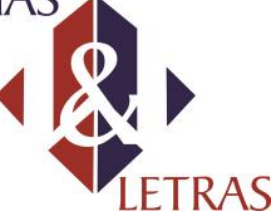

\title{
A Intertextualidade Como Um Critério de Coerência/Coesão
}

\author{
Intertextuality as a criteria Consistency/Cohesion
}

\author{
José Olavo da Silva Garantizado Júnior* \\ * Universidade Federal do Ceará, UFC, Fortaleza - CE, 60020-181, \\ e-mail:garantizadojunior@gmail.com \\ Mônica Magalhães Cavalcante** \\ ** Universidade Federal do Ceará, UFC, Fortaleza - CE, 60020-181, \\ e-mail:monicamc02@gmail.com
}

RESUMO: A presente pesquisa tem como objetivo analisar como a intertextualidade constitui-se como um critério de coerência/coesão. Para isso, a base teórica será, sobre a visão de coerência/coesão, Cavalcante (2011) e Garantizado Júnior (2011), que propuseram as relações dos fenômenos intertextuais e a definição da coerência, sobre intertextualidade, Koch, Bentes e Cavalcante (2007), que propuseram uma visão mais ampla do fenômeno em análise. Metodologicamente, esta pesquisa possui caráter documental, pois serão analisados textos já previamente divulgados em documentos oficiais e nas grandes mídias. Os resultados apontam que a intertextualidade stricto sensu, como defendem Koch, Bentes e Cavalcante (2007), é um dos fatores para a geração dos sentidos de um texto, configurando-se como um importante critério da abordagem conceitual da coerência/coesão.

PALAVRAS-CHAVE: Intertextualidade; Coerência/coesão; Fatores de textualidade;

ABSTRACT: The present research aims to analyze how intertextuality constitutes a criterion of coherence / cohesion. For this, the theoretical basis will be, on the vision of coherence / cohesion, Cavalcante (2011) and Garantizado Júnior (2011), who proposed the relations of intertextual phenomena and the definition of coherence, on intertextuality, Koch, Bentes and Cavalcante (2007) ), who proposed a broader view of the phenomenon under analysis. Methodologically, this research has documentary character, because will be analyzed texts already previously published in official documents and in the great media. The results show that the intertextuality stricto sensu, as defended by Koch, Bentes and Cavalcante (2007), is one of the factors for the generation of the meanings of a text, constituting an important criterion of the conceptual approach of coherence /cohesion.

KEYWORDS : Intertextuality ; Coherence /cohesion; Textuality Factors;

\section{INTRODUÇÃO}

A partir da década de oitenta, os pesquisadores de Linguística de Texto, em especial no Brasil, debruçaram-se em estudar, além dos fatores de textualidade em si, quais os tipos de relações intertextuais mais presentes nos textos. Assim, o estudo desse fenômeno passou por diversas abordagens e perspectivas, desde Koch (1985) até os Volume 18 


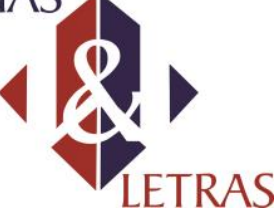

e-ISSN: 1981-4755

DOI: $10.5935 / 1981-4755.20170029$

recentes trabalhos de Koch, Bentes e Cavalcante (2007). Dentro dessas diversas maneiras de entender esse objeto de estudo, essas últimas autoras tiveram merecido destaque por, em seu modelo, desenvolverem uma divisão do fenômeno intertextual em duas abordagens: intertextualidade em sentido amplo (fundamenta-se, basicamente, no sentido bakhtiniano de dialogismo) e a intertextualidade em sentido stricto seno (que estariam ligadas aos tipos de relações intertextuais, destacando-se a intertextualidade implícita em oposição à explícita, as intertextualidades temática, estilística, tipológica, intergenérica e o détournement).

Com efeito, este artigo tem abjetiva analisar como a intertextualidade constituise um dos critérios definidores da coerência/coesão. Esta nova maneira de entender a coerência e a coesão como sendo inseparáveis é oriunda dos achados de Cavalvante (2011), quando apresenta necessidade de haver trabalhos que pudessem indicar critérios menos voltados para os aspectos semântico-formais para se definir, por exemplo, os elos coesivos sequenciais. Esse pensamento influenciou sobremaneira a proposta de Garantizado Júnior (2011) que indicou uma abordagem preliminar de definição da coerência/coesão, levando-se em conta aspectos de natureza sócio-históricos, sociocognitivos e interacionais, dentre eles, a intertextualidade.

Entendendo que a coerência/coesão é um fenômeno que deve ser considerado como um contínuo, seguindo as orientações teóricas de Cavalcante (2011) e Garantizado Júnior (2011), será examinado, neste trabalho:

(i) quais as categorias definem a coerência/coesão, a partir da proposta de Garantizado Júnior (2011);

(ii) como a noção de intertextualidade stricto sensu se configura na proposta de definição da coerência/coesão;

Para fins de organização dos dados e dos resultados, optou-se por seguir com os debates teórico e analítico conjuntamente, começando pelas estratégias argumentativas, seguindo pelas relações interdiscursivas e finalizando com as representações sociais.

\section{A DEFINIÇÃO DA COERÊNCIA/COESÃO E SUAS CATEGORIAS DE ANÁLISE}

Nas pesquisas desenvolvidas pelos Grupos de Estudos Protexto (UFC), Texto, Discurso e Ensino (TEDE/UNILAB) e pelo Grupo de Estudos em Linguística Textual (GELT/UNILAB), observou-se que definir os processos de geração de sentidos de um 


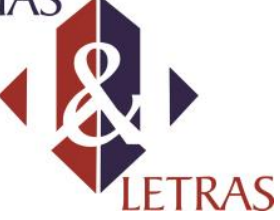

texto tornou-se uma tarefa instigante para vários pesquisadores (HALLIDAY; HASAN, 1976; BEAUGRANDE; DRESSLER，1981; CHAROLLES，1978; KOCH，2004; COSTA VAL, 2006, CAVALCANTE, 2011). No Brasil, esse percurso pelo qual passou a Linguística Textual repercutiu principalmente nos trabalhos de Koch, como se pode conferir nos seguintes trechos:

As exposições até aqui (...) agora pedem uma concepção de texto que não o veja como um mero artefato linguístico transparente, unívoco e que funcione por si mesmo. Muito menos que seja apenas uma unidade semântica portadora de informações linguisticamente codificadas. Para tanto, adoto a noção de texto tal como proposta por Beaugrande (1997, p.10) quando diz:

A partir desse momento, com o desenvolvimento cada vez maior das investigações na área de cognição, as questões relativas ao processamento do texto, em termos de produção e compreensão, às formas de representação do conhecimento na memória, à ativação de tais sistemas de conhecimento por ocasião do processamento, às estratégias sociocognitivas e interacionais nele envolvidas, entre muitas outras, passaram a ocupar o centro dos interesses de diversos estudiosos do campo (KOCH, 2004, p.2).

Foram principalmente esses estudos que, respaldando nossas concepções, advogaram em favor de um ponto de vista que segue as tendências sociocognitivas e discursivas das análises textuais de hoje. Neste trabalho, pensa-se que os fenômenos da coerência e da coesão não estão relacionados apenas ao que é de natureza interna do texto (aos mecanismos intratextuais que, em outras pesquisas, seriam atribuídas somente à coesão e à coerência semântica), mas, sim, também a fatores de natureza pragmática, cognitiva e sociointeracional. Essa congruência de fatores, que acabam por não distinguir entre o que é eminentemente intra e extralinguístico, leva-nos a propor o par indissociável coerência/coesão. Como dissemos em trabalho anterior:

partimos (...) de uma noção de texto como fenômeno comunicativo, o que supõe uma visão de coerência/coesão e de textualidade que não depende exclusivamente de propriedades inerentes à organização dos elementos no cotexto, mas, sim, de um contexto sociocultural mais amplo, o que inclui uma série de atividades interpretativas dos coenunciadores (CAVALCANTE, 2011, p. 9 [grifos nossos])

Em Cavalcante (2011), percebemos que foi seguida a mesma linha de raciocínio de Hanks (2008), para quem há textos que podem falhar em ter uma unidade temática, estilística ou outros tipos de unidade, mas nem isso os impede de ser um texto. Para o autor, as propriedades formais e funcionais de signos complexos também auxiliam no estabelecimento da textualidade e da sua coerência. Vejamos o exemplo a seguir: 


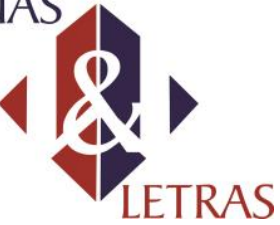

(1) Advertências portuguesas - ESPANTOSO....

Num secador de cabelos:

'NAO USE QUANDO ESTIVER DORMINDO'

(Sei lá, você pode querer ganhar tempo...)

Na embalagem do sabonete antisséptico Dial:

'INDICAÇÕES: UTILIZAR COMO SABONETE NORMAL'

(Boa! Cabe a cada um imaginar pra que serve um sabonete anormal)

Em alguns pacotes de refeições congeladas Swan:

'SUGESTÃO DE APRESENTAÇÃO: DESCONGELAR PRIMEIRO'

(É só sugestão, tá ok? De repente o pessoal pode estar a fim de chupá-las

como picolé.)

Numa touca para a ducha:

'VÁLIDO PARA UMA CABEÇA'

(Alguém muito romântico poderia colocar a sua e a da amada na mesma touca.)

Na sobremesa Tiramisú da marca Tesco, impresso no lado de baixo da caixa:

'NÃO INVERTER A EMBALAGEM'

(Ops! Já era... Inverteu!)

No pudim da Marks \& Spencer:

'ATENÇÃO: O PUDIM ESTARÁ QUENTE DEPOIS DE AQUECIDO'

(Brilhante!)

Na embalagem do ferro de passar Rowenta de fabricação alemã:

'NÃO ENGOMAR A ROUPA SOBRE O CORPO'

(Gostaria de conhecer a infeliz criatura que não deu ouvidos a este aviso.)

(...)

Disponível

em:

http:www.juraemprosaeverso.com.br/HumorDoPovoBrasileiro/Coisasdosportugueses.htm Acesso em 21de jul. de 2012.

Em (1), vemos pequenos conjuntos aparentemente soltos de citações findadas com enunciados de outra voz que comenta sobre os conteúdos mencionados. Não fossem o título e o site de humor de onde o texto foi extraído, de que decorrem as expectativas do internauta, os blocos de frases pareceriam desconexos, não coesos, haja vista que eles misturam diversificadas temáticas, o que poderia parecer descontinuidade tópica. Mas é o tópico geral que o título encapsula que une coerentemente os conteúdos num mesmo propósito de estabelecer humor. Esses aspectos, juntos, relacionam também os referentes e promovem a coesão referencial, pela ligação pragmático-discursiva entre as expressões referenciais e os conhecimentos de mundo convocados pelo cotexto.

O sentido do texto se dá a partir de uma série de fatores que devem ser levados em conta para que tenhamos a coerência/coesão textual, dentre eles as características 


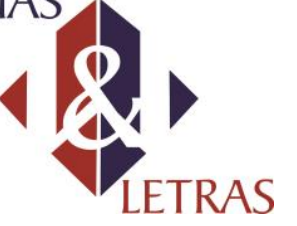

estruturais de um gênero, os discursos que se entrecruzam no texto, o entorno social da época e os propósitos comunicativos.

Defendemos que a coerência e a coesão estão, dessa forma, unidas, em qualquer texto, concepção que, de alguma forma, Koch, Bentes e Cavalcante (2007) já vinham apresentando em suas pesquisas, como podemos observar a seguir:

\begin{abstract}
coesão e coerência não podem ser vistas de forma totalmente estanques, visto que, na construção de ambas, operam processos de ordem cognitiva, de tal modo que se deveria pensar em contínuo: haveria alguns fenômenos mais típicos da coesão (por exemplo, as anáforas diretas correferenciais), e outros mais típicos de coerência (detecção da presença da intertextualidade, construção da macroestrutura global do texto), caminhando-se de um polo a outro do contínuo conforme a complexidade das inferências como a referenciarão, a interpretação de enunciados justapostos sem presença de articuladores, haveria uma imbricação necessária entre coesão e coerência, pois estaria em jogo um "cálculo de sentido" $(\mathrm{KOCH}$, BENTES, CAVALCANTE, 2007, p. 12-13).
\end{abstract}

Os achados de Cavalcante (2011) possibilitou a construção, por parte de Garantizado Júnior (2011), de uma noção preliminar de formação de uma proposta de análise da coerência/coesão que amalgamasse uma série de categorias já existentes na literatura especializada, que podemos ter como exemplo.

Recebe destaque, na proposta de Garantizado Júnior (2011), os estudos acerca da coerência e da coesão nos trabalhos de Charolles (1988), com suas "meta-regras" (a progressão, a repetição, a não contradição e a relação) e, posteriormente, nos de Costa Val (2006), que fez uma adaptação ao modelo de Charolles (1988), apresentando como fatores a continuidade, a progressão, a não contradição e a articulação. Em ambos os trabalhos, o cerne da questão é tomar a coerência como um princípio de interpretação do discurso e das ações humanas em geral. Para ambas as perspectivas, a coerência é vista como uma atividade interpretativa e não como uma propriedade imanente ao texto. Contudo, os critérios propostos pelos autores, de certa forma, não deixam de tomar a coesão somente na acepção de emprego de elos coesivos.

Para Garantizado Júnior (2011), a coerência/coesão se dá tomando-se como base também os fatores propostos por Beaugrande e Dressler (1981), Charolles (1988), Koch e Travaglia (2008) e Costa Val (2006), além de diversos fatores sociocognitivos, que ativam conhecimentos compartilhados. Segundo ele,

não estamos defendendo que o fenômeno da coerência/ coesão se dá a partir da união de todas essas perspectivas em um só momento ou que a falta de um desses fatores possa propiciar a falta de 
coerência/coesão, pois ver o fenômeno dessa forma, para nós, seria fazer uma junção de perspectivas teóricas com objetivos e propósitos diferentes. Na verdade, o que queremos demonstrar é que o fenômeno é muito mais complexo e não se limita somente aos mecanismos de coesão (tradicionalmente chamados na literatura especializada de elos coesivos). Dessa maneira, tivemos que levar em conta o que já foi dito por outros teóricos (GARANTIZADO JÚNIOR, 2011, p.73).

Como se pode perceber, o pesquisador usa de alguns critérios já existentes na literatura sobre o assunto para indicar a sua proposta. É inegável que, para que um texto tenha sentido, devemos saber a situação em que ele foi produzido, bem como quem o fez e para quem o fez, assim como qual a intenção que o produtor o fez e como o leitor o recebeu, quais as informações que o texto possui. Todavia, outros aspectos podem ser acrescentados aos que já foram analisados anteriormente. Estudos em Linguística de Texto sobrevalorizaram os processos de referenciação (CUSTÓDIO FILHO, 2006) e o tópico discursivo (ALENCAR, 2009) são indispensáveis à construção da coerência textual, por isso tais fenômenos também serviram de base para a proposta de Garantizado Júnior (2011).

Entendemos que o redimensionamento da coerência textual se dará quando levarmos em consideração todos esses aspectos (linguísticos, pragmáticos, sociocognitivos, sociointeracionais e culturais). Nesse contexto, observemos quais são as categorias usadas pelo pesquisador para definir a coerência/coesão, assim como a definição central usada por ele para justificar o uso da noção em sua proposta:

a) Situacionalidade: "O sentido, dessa forma, é estabelecido, levando-se em conta a situação em que um texto é utilizado. Por conta disso, a situação comunicativa é um dos fatores primordiais no processo de geração de sentido" (GARANTIZADO JÚNIOR, 2015, p. 73);

b) Intencionalidade : "o uso da linguagem por um determinado sujeito se dá, por si só, de maneira bastante argumentativa, isto é, o falante sempre tem intenções específicas de agir sobre os seus alocutários enquanto se comunica" (GARANTIZADO JÚNIOR, 2015, p. 77);

c) Aceitabilidade: "A aceitabilidade é um fator que está diretamente relacionado com a maneira como o receptor (alocutário) do texto o vê, recebendo-o como aceitável, dotado de significação e passível de uma interpretação" (GARANTIZADO JÚNIOR, 2015, p. $80)$;

d) Informatividade: "o grau de informatividade de um texto é importante para o processo de compreensão textual. (...) O alto grau de informações pode fazer com que os sujeitos que estão tentando calcular os sentidos do texto apelem para outros fatores que não sejam apenas linguísticos" (GARANTIZADO JÚNIOR, 2016, p. 88);

e) Intertextualidade: "reconhecer o intertexto e os seus vários desdobramentos na produção dos sentidos é um fator essencial para a apreensão dos conteúdos que são expostos na superfície textual" (GARANTIZADO JÚNIOR, 2011, p. 89).

f) Conhecimento linguístico: "abrange o conhecimento gramatical e lexical (...) é a partir desse tipo de conhecimento que podemos compreender, por exemplo, a organização do material linguístico na superfície textual" (GARANTIZADO JÚNIOR, 2011, p. 102);

Volume 18

Número 41 
g) Conhecimento de mundo: "se refere a conhecimentos gerais sobre o mundo, bem como a conhecimentos alusivos a vivências pessoais e a eventos temporalmente situados, permitindo a produção de sentidos" (GARANTIZADO JÚNIOR, 2011, p. 103).

h) Conhecimento interacional: "interacional. De acordo com as autoras, esse tipo de conhecimento se refere às formas de interação por meio da linguagem" (GARANTIZADO JÚNIOR, 2011, p. 103);

i) Tópico discursivo: "uma unidade de estatuto textual-discursivo que é usada no processo de estruturação e na organização de partes de unidade de conteúdo de um texto (macroestrutura), e que faz com que tenhamos o desenvolvimento da coerência textual" (GARANTIZADO JÚNIOR, 2011, p. 113);

j) Processos referenciais: "A referenciação constitui, portanto, uma atividade discursiva. $O$ sujeito, por ocasião da interação verbal, opera sobre o material linguístico que tem à sua disposição e sobre escolhas significativas para representar estados de coisas, de modo condizente com a sua proposta de sentido" (GARANTIZADO JÚNIOR, 2015, p. 121).

Como se pode perceber, dentre os fatores que determinariam (ou poderiam possibilitar a coerência/coesão) está a intertextualidade, nosso objeto de investigação neste artigo. Nesse sentido, passemos para a análise desse fenômeno sob à luz dos estudos de Koch, Bentes e Cavalcante (2007), assim como os exemplos encontrados em diversas situações comunicativas.

\section{INTERTEXTUALIDADE E SUAS IMPLICAÇÕES TEÓRICAS NA COERÊNCIA/COESÃO}

Pensar a intertextualidade como um critério definidor da coerência/textual é, em linhas gerais, indicar similaridades com o pensamento de Beaugrande e Dressler (1981). No entanto, o rigor para a preocupação dos aspectos semânticos, principalmente, com relação aos elos coesivos, possibilita-nos a nos orientar, como já falamos, ao modelo indicado por Cavalcante (2011).

Na proposta de Koch, Bentes e Cavalcante (2011), a intertextualidade se mostra como um fenômeno com características estruturais e/ou estilísticas e, assim, ela representa um dos importantes elementos que propicia o processamento da leitura dos mais diversificados tipos de textos, sejam eles verbais ou até mesmo não verbais. Não se pode esquecer, também, que, nesta mesma maneira de concebê-la, entende-se que os sentidos que se fazem presentes em uma dada superfície do texto só serão devidamente apreendidos na medida em que os interlocutores tiverem armazenadas em sua memória informações que lhes possibilitem reconstruir os sentidos e as referências.

A importância da memória, a nosso ver, dá-se pelo fato de que, sem a sua ativação, fica inviável (ou pelo menos mais difícil) o pleno entendimento do que está sendo dito pelo produtor, pois o intertexto, de certa forma, constitui-se como sendo um elemento que pode mediar os sentidos entre os interlocutores. 


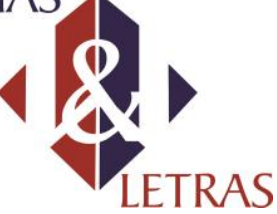

e-ISSN: 1981-4755

DOI: $10.5935 / 1981-4755.20170029$

Koch, Bentes e Cavalcante (2007) propõem uma divisão do fenômeno da intertextualidade em dois tipos: a stricto sensu e a lato sensu. Para nós, esta subdivisão apresenta-se como uma tentativa das autoras, bem sucedida, diga-se de passagem, de determinar o grau de explicitação e até mesmo a natureza do intertexto que é usado na composição textual.

Comecemos, pois, pela intertextualidade stricto sensu. Segundo as autoras, este tipo ocorre quando temos um intertexto que "faz parte da memória social de uma coletividade" (KOCH; BENTES; CAVALCANTE, 2007, p. 17) e ele é inserido em um novo texto, fazendo parte da memória coletiva. Não se pode deixar de se levar em conta os vários tipos de intertextualidade stricto sensu, cada um com suas próprias características, que já foram estudadas. Quanto a isso, as autoras, em seus achados, apresentam-nos alguns tipos, a saber: a intertextualidade temática, a intertextualidade estilística, a intertextualidade explícita, a intertextualidade implícita e o détournement (caso de intertextualidade implícita, segundo as autoras).

Comecemos uma breve análise de como essas formas de intertextualidade podem contribuir para que o texto possua coerência/coesão. Para tal, iniciemos com a intertextualidaade temática. Para Koch, Bentes e Cavalcante (2007), esse tipo de intertextualidade é encontrado em diversas situações comunicativas, tais como em textos científicos pertencentes a uma mesma área do saber, que partilham temas e se servem de conceitos e terminologias próprias, já definidos no interior dessa área ou corrente teórica; em matérias de jornais e da mídia em geral; em as revistas semanais e nas matérias jornalísticas da semana; em textos literários de uma mesma escola ou de um mesmo gênero, como ocorre nas epopeias, em histórias de quadrinhos de um mesmo autor, em diversas canções de um mesmo compositor ou de compositores diferentes e nas mesmas encenações de uma mesma peça de teatro, entre outras.

Um bom exemplo desse tipo de intertextualidade é a relação entre o tema da Medeia de Eurípedes, da Medeia de Sêneca e a peça Gota d'água de Chico Buarque de Holanda e Paulo Pontes. Nos textos clássicos de Medeia, temos uma relação com as tradições e os mitos gregos. Assim, de acordo com o que diz a lenda grega, Medeia seria uma feiticeira que teria ajudado Jasão, um importante líder dos argonautas, a obter o velocino de ouro. No entanto, esse mito se tornou conhecido pelas várias versões literárias que lhe deram Eurípides, Ésquilo, Ovídio e Sêneca.

Nas versões literárias, por sua vez, Medeia era filha de Eetes, rei da Cólquida. Eetes possuía o velocino de ouro, que Jasão e os argonautas buscavam, e o mantinha Volume 18 Número 41 


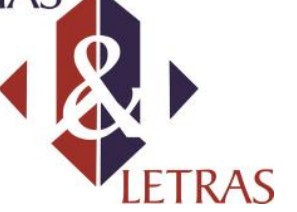

e-ISSN: 1981-4755

DOI: $10.5935 / 1981-4755.20170029$

guardado por um dragão. A maga Medeia apaixonou-se por Jasão e, depois de ajudá-lo a realizar sua missão, seguiu com o grupo para a pátria de Jasão, Jolcos, na Tessália. Mais tarde, Jasão apaixonou-se por Glauce e abandonou Medeia. Inconformada, ela estrangulou os filhos que tivera com Jasão e presenteou a rival com um manto mágico que se incendiou ao ser vestido, matando-a.

Na peça Gota D'água, os fatos ocorrem em um vilarejo pobre do Rio de Janeiro - a "Vila do Meio-dia" - na qual mora a protagonista Joana, uma bela moça apaixonada por Jasão, um sambista que alcança a fama e a trai com uma mulher mais jovem e rica (justamente a filha do dono deste conjunto habitacional). A ambição de Jasão representa não somente a traição à sua mulher, mas também uma traição a todo um povo reprimido que trava batalhas todos os dias pelo seu sustento. Como Joana havia se sacrificado pela carreira e pelo crescimento pessoal de seu marido, esta resolve vingar-se, tentando matar a futura noiva e o sogro de Jasão. Por não ter conseguido o que pretendia, a protagonista mata os filhos que teve com ele, suicidando-se logo em seguida como protesto.

Como se pode notar, os textos assemelham-se quanto às temáticas que tentam apresentar. Os fatos de Gota D'água, por exemplo, em vários momentos, relacionam-se com os das Medeias dos textos literários gregos: a traição de Jasão a Medeia, o fato de Jasão trocá-la por uma mulher mais jovem, Medeia ficar furiosa e matar os filhos que tivera com Jasão, entre outros fatos que fazem com que tenhamos uma nítida relação intertextual por semelhança entre temas abordados nos texto. Como ficou evidente, as relações entre as peças se dão a partir das temáticas existentes nelas, tais como o ato passional das protagonistas, que, para nós, buscarem não somente a morte de seus filhos, mas também o suicídio, demonstra a busca desesperada por justiça. Elas são personagens que possuem fé e esperança de que serão vingadas espiritualmente tanto como mulheres, quanto como cidadãs que sofrem pela pobreza. Representando um povo que batalha todos os dias, Medeia e Joana enxergaram, em suas mortes e no assassinato de seus filhos, uma chance de alcançar o paraíso e uma vida.

Outro tipo de intertextualidade apresentado por Koch, Bentes e Cavalcante (2007) e que consideramos no processo de contribuição de geração dos sentidos (GARANTIZADO JÚNIOR, 2011) é a intertextualidade estilística. Esse tipo de relação intertextual ocorre quando o produtor do texto, com objetivos variados, repete, imita certos estilos ou variedades linguísticas. Para exemplificarmos esse tipo de intertextualidade, olhemos para o texto abaixo:

Volume 18

Número 41 


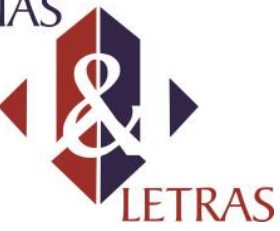

e-ISSN: 1981-4755

(2) Quem prefere enfartar? Levanta a mão! ${ }^{1}$

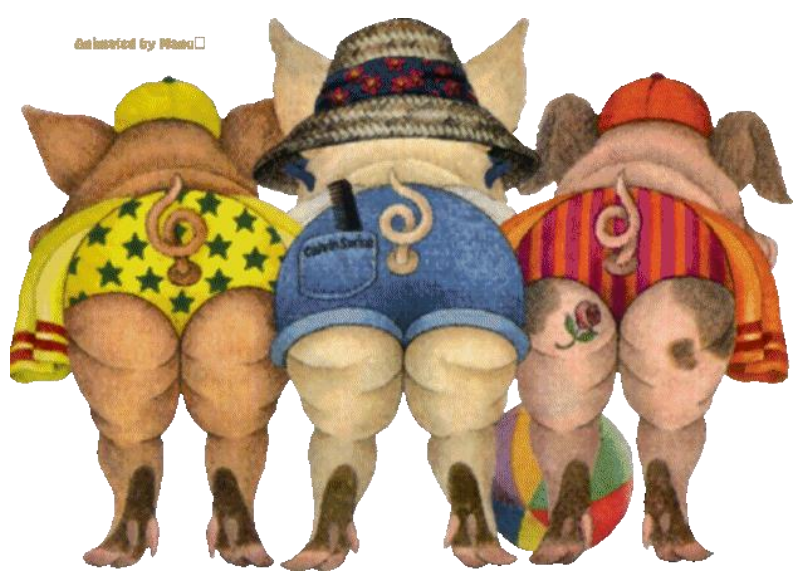

A celulite é uma defesa orgânica feminina.

O organismo joga ali, na sua bunda, o excesso de gordura que você come, em vez de entupir suas artérias; por isso homens enfartam em maior quantidade que as mulheres.

Eu tinha certeza de que havia um motivo...

Deus não seria tão injusto!

Fonte: Material da disciplina de Texto e Discurso da Educação à Distância da UFC-VIRTUAL

Em (2), temos uma imitação do estilo da linguagem presente em textos científicos. Temos uma relação intertextual que se dá de maneira intergenérica, pois o produtor do texto conta, de certa forma, com o conhecimento prévio dos seus ouvintes/leitores a respeito dos gêneros em questão. Segundo Koch, Bentes e Cavalcante (2007), esse tipo de texto é muito comum em gêneros como a fábula, os contos infantis, as cartas, em colunas opinativas dos jornais, bem como nos gêneros de caráter parodístico, irônico e/ou argumentativo, inclusive em charges políticas. Assim, podemos falar que a intertextualidade intergenérica, para nós, sempre será um tipo de intertextualidade estilística, por conta da imitação do estilo a ser produzido no texto.

No texto em questão, o produtor inicia falando acerca de um problema sério, no caso, do "enfarto". Logo no início, uma pergunta é usada com o objetivo de chamar a atenção do leitor “quem prefere enfartar? Levanta a mão!”. No entanto, após o texto inicial, uma figura nos é mostrada, três porcos fêmeas de costas, trajadas com roupas femininas típicas do uso em uma praia. Isso faz com que tenhamos uma relação entre a figura e as mulheres que vão com esse tipo de vestimenta para o referido lugar. Abaixo da figura, a continuação do texto, primeiro explicando o que é a celulite ("a celulite é uma defesa orgânica feminina") e, depois, um trecho que se estrutura de maneira irônica, propiciando sentido que o texto quer nos mostrar ("o organismo joga ali, na sua

\footnotetext{
${ }^{1} \mathrm{O}$ exemplo foi retirado do material usado pela Profa. Monica Magalhães Cavalcante em uma Disciplina da Educação a Distancia (EaD) da UFC-Vitrual.

Volume 18

Número 41
} 


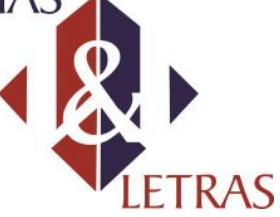

bunda, o excesso de gordura que você come, em vez de entupir suas artérias; por isso homens enfartam em maior quantidade que as mulheres"). A relação entre o contexto cotidiano de um ambiente de praia com a linguagem científica se configura de maneira irônica, mais adiante, com a frase "Eu tinha certeza de que havia um motivo...", que faz alusão ao fato de apenas as mulheres terem celulite e não os homens. O texto se faz de maneira irônica e se configura a partir da junção de vários gêneros e faz com que se constitua uma memória coletiva em que o leitor constrói o sentido baseado na busca de interpretar as informações apresentadas.

Outro tipo de intertextualidade mostrada pelas autoras, e seguida na abordagem de Garantizado Júnior (2011), foi a explícita. Segundo as autoras,

a intertextualidade será explícita quando, no próprio texto, é feita a menção à fonte do intertexto, isto é, quando um outro texto ou um fragmento é citado, é atribuído a outro enunciador; ou seja, quando é reportado como tendo sido dito por outro ou por outros generalizadores ('Como diz o povo...', 'segundo os antigos...') (KOCH; BENTES; CAVALCANTE, 2007, p. 28).

As autoras continuam falando que esse tipo de relação intertextual é bastante comum em situações, tais como: quando citamos um determinado texto, quando fazemos uma referência, uma menção, um resumo, uma resenha e uma tradição, por exemplo. Ela aparece também em textos argumentativos, quando empregamos o recurso à autoridade; e, em se tratando de interação do tipo face a face, nas retomadas do texto do parceiro, para encadear sobre ele ou contradizê-lo.

Abaixo, apresentaremos uma das situações descritas anteriormente, ou seja, temos um exemplo de intertextualidade explícita, usada por Koch e Travaglia (2008) com o argumento de autoridade, como recurso para exemplificar uma determinada posição teórica que esta pesquisadora seguiria:

(3):

O pressuposto geral deste trabalho é que a referência por meio de formas nominais consiste na construção e reconstrução de objetos-dediscurso, posição que se encontra assim explicitada em Apothéloz e Reichler-Béguelin (1995, p. 228):

De maneira geral, argumentamos (...) em favor de uma concepção construtivista da referência (...); assumiremos plenamente o postulado segundo o qual os chamados "objetos-de-discurso" não preexistem "naturalmente" à atividade cognitiva e interativa dos sujeitos falantes, mas devem ser conhecidos como produtos (fundamentalmente culturais) desta atividade. 


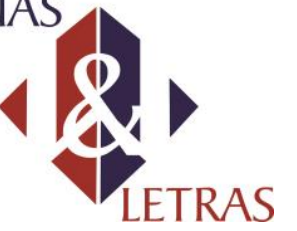

e-ISSN: 1981-4755

DOI: $10.5935 / 1981-4755.20170029$

Outra maneira de termos a intertextualidade explícita é através da retomada da fala do parceiro em uma dada interação face a face, como é o caso do texto abaixo, retirado de Koch, Bentes e Cavalcante (2007):

(4):

- Mãe, o dia ensolarado!

- O dia ensolarado? Então podemos fazer o piquenique que tínhamos combinado.

Koch, Bentes e Cavalcante (2007) nos falam também da intertextualidade implícita. Para as autoras, esse tipo se dá quando se introduz, no próprio texto, intertexto alheio, sem qualquer menção explícita da fonte, com o objetivo quer de seguir-lhe a orientação argumentativa, quer de contraditá-lo, colocá-lo em questão, ou argumentar em sentido contrário. De acordo com Garantizado Júnior (2011), o processo de geração de sentidos desse tipo de intertextualidade se dá a partir da ativação de uma série de conhecimentos compartilhados, principalmente os relacionados a uma memória coletiva, já que, para que tenhamos o sentido, o receptor deve ativar o texto-fonte em sua memória.

Grésillon e Maingueneau (1984) nos falam de duas maneiras de termos a intertextualidade implícita: a captação (paráfrases próximas do texto-fonte) e a subversão (enunciados parodísticos e/ou irônicos, apropriações, reformulações de tipo concessivo, inversão de polaridade, afirmação/negação, entre outros).

Um exemplo de subversão é o texto "Bom conselho", de Chico Buarque de Holanda, em que este procede a uma série de subversões a alguns provérbios muito conhecidos. Observemos o texto:

(5):

Bom conselho

(Chico Buarque)

Ouça um bom conselho

Que eu lhe dou de graça

Inútil dormir que a dor não passa

Espere sentado

Ou você se cansa

Está provado, quem espera nunca alcança

Venha, meu amigo

Deixe esse regaço

Brinque com meu fogo

Venha se queimar

Faça como eu digo

Volume 18

Número 41 


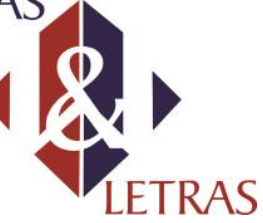

Faça como eu faço

Aja duas vezes antes de pensar

Corro atrás do tempo

Vim de não sei onde

Devagar é que não se vai longe

Eu semeio o vento

Na minha cidade

Vou pra rua e bebo a tempestade

Fonte: www.vagalume.com.br. Acesso em 12 de jul. de 2012.

Acerca do processo intertextual presente no texto acima, Koch, Bentes e Cavalcante (2007) defendem:

\begin{abstract}
nesses casos de enunciação de origem desconhecida, como provérbios, frases feitas, ditos populares, que fazem parte da cultura do povo e que se repetem anonimamente através do tempo, a fonte é um enunciador genérico, representante da sabedoria popular, da opinião pública (...). Trate-se de 'enunciações-eco' de um número ilimitado de enunciadores anteriores, avalizados por ser um enunciador genérico, que é o representante do "Vox populi", do saber geral da comunidade no interior da qual aquelas são re-enunciadas, de modo que a recuperação é praticamente certa (KOCH; BENTES, CAVALCANTE, 2007, p. 33).
\end{abstract}

O texto de Chico Buarque desconstrói uma série de provérbios que são do conhecimento geral, logo pertencem a um enunciador geral, como já falaram as autoras anteriormente. Em um provérbio como "Está provado, quem espera sempre alcança", Chico Buarque usa da artimanha da contradição para transformá-lo, subvertê-lo em "Está provado quem espera nunca alcança"; quanto ao provérbio "Faça o que eu digo, não faça o que eu faço", Chico Buarque transforma-o em "faça como digo, faça como eu faço" e assim por diante.

As autoras nos apresentam o texto de Gonçalves Dias, "Canção do exílio", como sendo um dos que mais proporcionam relações intertextuais. Na verdade, esse texto faz relações ora de captação, ora de subversão com outros textos. Para elas, os poemas "Canção do exílio", de Casimiro de Abreu, "Nova canção do exílio", de Carlos Drummond de Andrade, trechos do Hino Nacional Brasileiro e da canção do expedicionário, "Canção do exílio facilitada", de José Paulo Paes, entre outros, segundo elas, subvertem o poema original, assim como "Canção do exílio", de Murilo Mendes; "Canto de regresso à pátria”, de Oswald de Andrade; "Canção do exílio", de Cassiano Ricardo", entre outros.

Atentemos para os dois exemplos abaixo, que se dão a partir de um processo de subversão por paródia:

Volume 18

Número 41 


\begin{tabular}{|c|c|}
\hline Sorte Grande (Poeira) & Sorte Grande \\
\hline (6): & (7): \\
\hline Sorte Grande (Poeira) & Sorte Grande \\
\hline Ivete Sangalo & \\
\hline A minha sorte grande, & A minha sorte grande \\
\hline Foi você cair do céu, & foi cair nessa excursão \\
\hline Minha paixão & com amizade verdadeira. \\
\hline verdadeira. & Só rola emoção, \\
\hline Viver a emoção, & Lília toca violão \\
\hline Ganhar teu coração, & E Goreti só fala besteira. \\
\hline Pra ser feliz a vida & Rebeca é mascote \\
\hline inteira... & Tancinha nossa guia \\
\hline É lindo o teu sorriso, & Madruga todo dia. \\
\hline O brilho dos teus olhos, & Tem Marcia e tem Marcio, \\
\hline Meu anjo querubim. & Tem Vilma e Zilma, \\
\hline Doce dos teus beijos, & Tem Telma e tem Elma. \\
\hline Calor dos teus braços, & Chegando em BH \\
\hline Perfume de jasmim... & De tudo pode rolar \\
\hline Chegou no meu espaço, & Muita comida mineira \\
\hline Mandando no pedaço, & Veio o motorista \\
\hline $\begin{array}{l}\text { Com o amor que não é } \\
\text { brincadeira. }\end{array}$ & $\begin{array}{l}\text { e se perdeu na pista } \\
\text { e a gente comendo poeira }\end{array}$ \\
\hline Pegou me deu um laço, & Poeira..a..a..\} $3 x$ \\
\hline $\begin{array}{l}\text { Dançou bem no } \\
\text { compasso, }\end{array}$ & Comendo poeira \\
\hline De prazer levantou & A minha sorte grande \\
\hline poeira. & foi cair nessa excursão \\
\hline Poeira (3x) & com amizade verdadeira. \\
\hline Levantou poeira! & Maria manda rezar \\
\hline Poeira $(3 \mathrm{x})$ & Será que vamos aguentar \\
\hline Levantou poeira! & viajar nessa geladeira. \\
\hline Fonte: & Motorista é carangueijo \\
\hline www.vagalume.com.br. & gosta de andar de ré \\
\hline Acesso em 12 de jul. de & Tõ quase indo a pé. \\
\hline 2012. &  \\
\hline & \\
\hline
\end{tabular}

Tabela 1- Comparação intertextual

Fonte: Elaboração nossa

Em (6) e (7), sistematizados na tabela 1, percebemos que há uma relação entre os dois textos a partir da tentativa, em (7), de transformar partes do texto "Sorte grande", da intérprete Ivete Sangalo, de forma intertextual. Ao fazer isso, a autora de (7) ressignifica a canção de Ivete com outras expressões que nos fazem remeter para a temática que a autora quer apresentar, no caso uma excursão realizada com alguns amigos. Confirma-se isso observando-se os trechos abaixo:

Volume 18

Número 41 
(8):

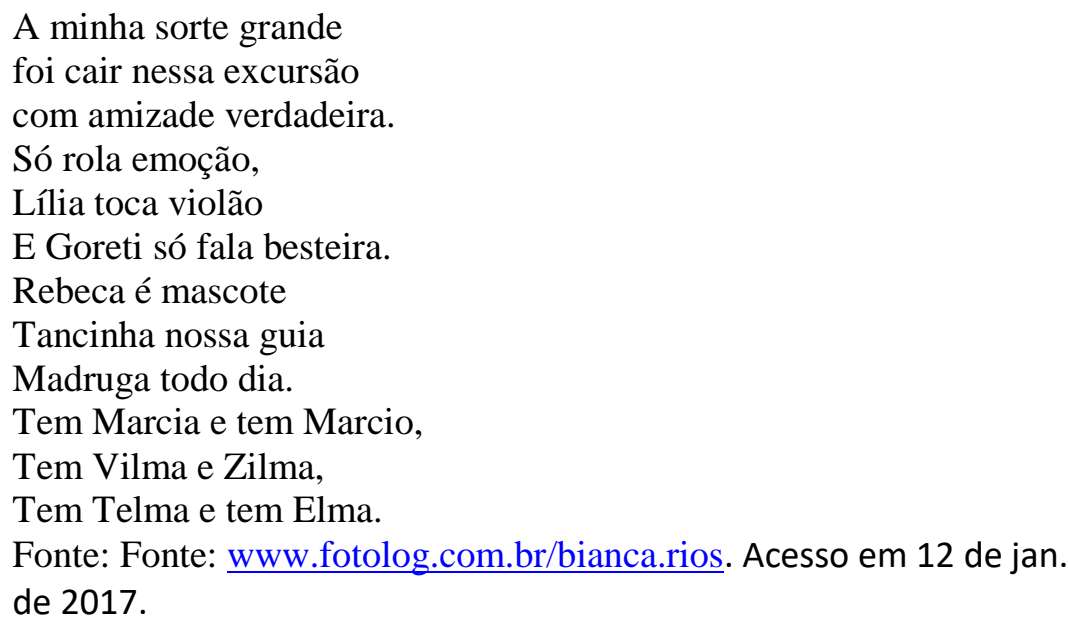

Comparando o trecho acima com o trecho da música cantada por Ivete Sangalo, percebemos que alguns itens lexicais foram modificados, mas se manteve parte da canção, buscou-se continuar com a ação melódica dela, o ritmo. Expressões como "minha sorte grande foi você cair do céu/ minha paixão verdadeira", no texto fonte, foram substituídas por "a minha sorte grande/ foi cair nessa excursão" no texto da blogueira. A palavra "excursão" substituindo "céu", que aparecia na versão original, modifica o sentido do texto, no entanto, mesmo com muitas mudanças elaboradas intencionalmente pelo texto da internauta, por conhecermos o texto da música de Ivete, a entonação, a estrutura, a forma como ela canta, as expressões, fazemos uma associação entre os dois textos, por isso se trata de um recurso intertextual denominado de paródia.

Não podemos deixar de falar também que a temática entre os textos não foi mantida, já que o texto da música da Ivete Sangalo fala de um amor novo, "que caiu do céu", enquanto que o texto da blogueira retrata uma viagem feita para Minas Gerais com seus amigos, o que é confirmado com a aparição de vários nomes próprios, que, provavelmente, são os amigos que estiveram presentes na viagem (Lília, Goreti, Rebeca, entre outros).

Abaixo, apresentaremos o texto original, o texto-fonte, "Canção do exílio", de Gonçalves Dias. Em seguida, um exemplo de um texto com vigor intertextual por captação, "Canção do exílio", de Casimiro de Abreu e, por último, um texto retirado da revista Lance.

(9):

Canção do Exílio (Gonçalves Dias)

Minha terra tem palmeiras

Volume 18

Número 41 
Onde canta o sabiá

As aves que aqui gorgeiam

Não gorgeiam como lá.

Nosso céu tem mais estrelas

Nossas várzeas têm mais flores

Nossos bosques tem mais vida

Nossa vida mais amores.

Não permita Deus que eu morra

Sem que volte para lá,

Sem que desfrute os primores

Que tais não encontro eu cá,

Sem que'inda aviste as palmeiras

Onde cata o sabiá.

Fonte: Dias (1959)

(10):

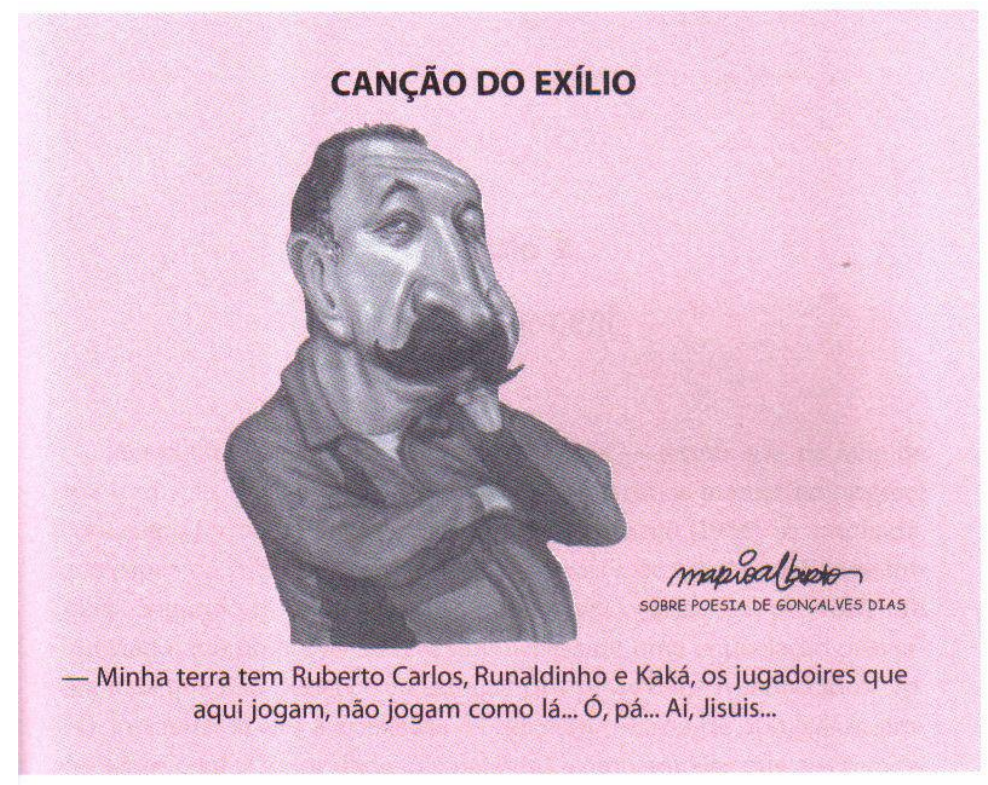

Fonte: Koch, Bentes e Cavalcante (2007, p. 43)

Como podemos perceber, o exemplo (10) foi retirado da revista Lance e também faz uma relação intertextual com o poema de Gonçalves Dias. Se atentarmos bem para o texto, perceberemos que um enunciador, na composição do texto, remete diretamente à memória discursiva dos interlocutores. Isso se dá a partir da relação existente entre a "Canção do exílio", de Gonçalves Dias, e a fala do técnico de futebol, Luís Felipe Scolari, reportando-se a alguns jogadores de futebol brasileiros que, no ano em que o texto fora produzido, estavam jogando na Europa. A relação entre o poema de Gonçalves Dias e o texto da revista Lance se dá pelo fato de que, no ano de 2004, Luís Felipe era o técnico da seleção de Portugal e, assim, estava exilado. Nesse sentido, há uma imbricação entre o gênero charge e o gênero poema, que, de certa forma, mesmo Volume 18 


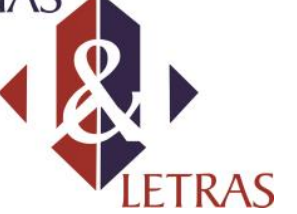

e-ISSN: 1981-4755

DOI: $10.5935 / 1981-4755.20170029$

sendo aparentemente distintos, estão convergindo no texto em destaque para o objetivo de que o sentido seja construído.

Dessa maneira, a intertextualidade stricto sensu apenas irá ocorrer com remissão a outros textos que já foram anteriormente produzidos e que devem remeter a elementos mais variados, podendo se dar apenas nas palavras ou até na própria estrutura textual.

Tomando a nossa visão do fenômeno da coerência/coesão, podemos perceber que a construção dos sentidos do texto se deu levando-se em consideração uma série de fatores de ordem pragmática, social e cognitiva. Importante dizer que o processo de construção textual se dá quando unimos os nossos conhecimentos de que o texto constitui uma charge (e tal gênero possui características específicas, entre elas a de propiciar o riso e o humor). Está se referindo a um poema de um autor, que, com saudade de sua terra natal, proferiu-o, aproveitando o momento de exílio em que se encontrava para valorizar e exaltar as belezas de sua terra. $\mathrm{O}$ título presente na charge "Canção do exílio" é proposital, pois o sujeito receptor vai ter que buscar na sua memória discursiva os motivos pelos quais um técnico de futebol está expressando saudade de jogadores brasileiros. Assim, o receptor terá que se reportar ao período histórico em que o texto fora produzido e poderá ver que, naquele período, Luís Felipe Scolari era o técnico da seleção portuguesa de futebol.

A ativação desse dado da memória faz com que tenhamos a geração de sentido entre o poema e a charge, pois esta dá uma nova significação para aquele. Isso advém da associação das belezas da terra natal, no poema, com o "senso comum" de que os jogadores brasileiros, em especial os citados na charge, no período de 2004, eram os mais valorizados, os que possuíam o chamado futebol-arte. O receptor, para que o sentido seja gerado de forma mais precisa ainda, terá que se situar um pouco antes, quando o mesmo técnico, Luís Felipe Scolari, dois anos antes de a charge ser produzida, era o técnico da seleção brasileira e conviveu com os jogadores citados por ele.

Percebemos que a charge se constrói como sendo um sentimento de saudade do técnico dos jogadores que ele, quando fora técnico da seleção brasileira, treinava. Isso se confirma precisamente com "os jogadores que aqui jogam não jogam como lá”, de modo que o "aqui" é uma alusão a Portugal e o "lá" ao Brasil.

Como ficou evidente, o sentido desse texto se deu com base em uma série de outros fatores que, se atentarmos bem, foram propiciados pela intertextualidade, mas que, para que esta pudesse propiciar o sentido, foi necessário ter em conta quem Volume 18 Número 41 


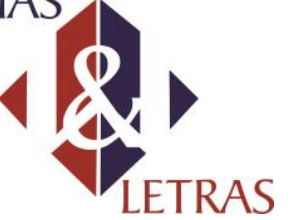

e-ISSN: 1981-4755

DOI: $10.5935 / 1981-4755.20170029$

produziu o texto, quem o recebeu, fatores ligados à memória, à situação comunicativa em que o texto fora produzido, o conhecimento de mundo do sujeito receptor, entre vários outros fatores que, para nós, estão presentes no processo de geração de sentidos e são critérios definidores deles na proposta de coerência/coesão. A intertextualidade é um importante fator que gera a coerência textual, pois, a partir dela, outros fatores são acionados. Por isso, uma série de conhecimentos são exigidos para que o receptor possa compreender de maneira satisfatória as informações, buscando sentido no texto.

\section{CONCLUSÃO}

Este trabalho demonstrou como a intertextualidade é um dos critérios definidores da noção de coerência/coesão, tomando-as como fenômenos indissociáveis, partindo dos achados de Cavalcante (2011) e Garantizado Júnior (2011). Sistematizamos os principais fatores que contribuem para que tenhamos a coerência/coesão, levando-se em consideração importantes teóricos Linguística do Texto.

Em nossa incursão teórica, não se pretendeu modificar a nomenclatura existente acerca dos fenômenos analisados, mas propusemos que o fenômeno da coerência/coesão seja visto como um contínuo, destacando a intertextualidade stricto sensu como um dos elementos definidores dessa importante noção teórica.

Finalmente, fomentamos uma discussão acerca da importância da intertextualidade e a sua aplicabilidade no modelo conceitual de definição da coerência/coesão. Entretanto, é fundamental que novos trabalhos possam comprovar como os demais fatores abordados na proposta aqui apresentada podem ser, de fato, critérios dessa nova abordagem teórica de definição dos sentidos do texto.

\section{REFERÊNCIAS}

ALENCAR, E. N. de. O tópico discursivo nas dissertações de alunos do ensino médio. Dissertação (Mestrado) - Universidade Federal do Ceará, Programa de Pós-Graduação em Linguística, Fortaleza, 2009.

BAKHTIN, M. M. Estética da criação verbal. São Paulo: Martins Fontes, 1997. 


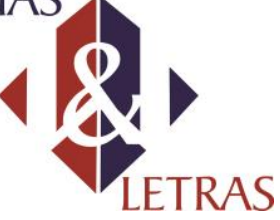

BEAUGRANDE, R.-A.; DRESSLER, W. U. Introduction to text linguistics. London and New York: Longman, 1981.

CAVALCANTE, M. M. Referenciação: sobre coisas ditas e não ditas. Fortaleza: Edições UFC, 2011.

CHAROLLES, M. Introdução aos problemas da coerência dos textos. Tradução Paulo Otoni. In: GALVES, C. ; ORLANDI, E. P.; OTONI, P. (Org.). O texto: escrita e leitura. Campinas: Pontes, 1988, p. 39-85.

COSTA VAL, M. da G. Redação e textualidade. $3^{\mathrm{a}}$. ed. São Paulo: Martins Fontes, 2006.

CUSTÓDIO FILHO, V. Expressões referenciais em textos escolares: a questão da (in) adequação. Dissertação (Mestrado em Linguística) - Programa de Pós-Graduação em Linguística, Universidade Federal do Ceará, Fortaleza, 2006.

DIAS, A. G. Poesias Completas e prosa escolhida. 1․ Ed. Rio de Janeiro: Aguilar, 1959.

GARANTIZADO JÚNIOR, J. O. S. Preliminares para a definição de coerência/coesão. Dissertação (Mestrado em Linguística) - Programa de PósGraduação em Linguística, Universidade Federal do Ceará, Fortaleza, 2011.

GRÉSILlON, A.; MAINGUENEAU, D. Poliphonie, proverce et détournement. Languages 73, 1984, pp. 122-25.

HANKS, W. F. Língua como prática social: das relações entre língua, cultura e sociedade a partir de Bourdieu e Bakhtin. Organização e apresentação de Anna Christina Bentes; Renato C. Rezende; Marco Antônio Rosa Machado. Tradução de Anna Christina Bentes; Marco Antônio Rosa Machado; Marcos Rogério Cintra; Renato C. Rezende. Revisão técnica de Anna Christina Bentes; Maurizio Gnerre. São Paulo: Cortez, 2008.

KOCH, I. G. V. A intertextualidade como critério de textualidade. In: FÁVERO, L. L; PASCHOAL, M. S. Z. (orgs.). Linguística textual e leitura. São Paulo: EDUC, 1985, p. $39-46$.

Introdução à linguística textual. São Paulo: Martins Fontes, 2004.

I. G. V.; MARCUSCHI, L. A. Processos de referenciação na produção discursiva. Revista DELTA, São Paulo, v. 14, 1998.

BENTES, A. C; CAVALCANTE, M. M. Intertextualidade: diálogos possíveis. São Paulo: Cortez, 2007. 2008. ., I. G. V.; TRAVAGLIA, L. C. Texto e coerência. 12a . ed. São Paulo: Cortez, 